\title{
Propeller Shaft in Automobile: Review the Allocation Procedure in Front Axle and springs
}

\author{
Dr Porag Kalita. Ph.D. (Auto. Engineering) \\ Head: Automobile Engineering Department, \\ Govt. of Assam,Vocational Education (+2), \\ M R S Higher Secondary School, Titabor, Assam. \\ Email: poragkalita@rediffmail.com
}

\section{Abstract:}

While vehicle on moving position, torque is converted from the rear wheel through the propeller shaft. The propeller shaft, which is transmit full engine power from the gear box to the differential and propeller shaft one end connected to the gear box, while the other is connected to the differential in the rear axle assembly. As per study it was found that while vehicle is moving on the curve road or angle in turning moment on the road surfaces, without propeller shaft may caused accident, if vehicle rear wheel drive. Because the distance between gear box and differential changes when the vehicle encounters an uneven surface. Axles act as axis for the wheels to spin around and it is consists by Live Axles and Dead Axle. For the example, live axle which contain differential and through rotary motion is transmitted to the wheels. Dead axle, which do not contain differential and these are simply beams which support the vehicle weight and serve as axis for the wheels. A coiled piece of round or square steel wire which, when compressed exerts, a force that may be used to do some work. Leaf springs or carriage springs are used in the vehicles to cushion the shocks imparted to the wheels by road obstacles.

Key Words: Hotchkiss drive, Leaf springs, Propeller Shaft, Rear and Front axle, Torque.

\section{INTRODUCTION:}

The main functions of propeller shaft that if transmits rotary motion and power to the differential. Propeller shaft consisting by three parts, i.e. hollow shaft, universal joints and slip joints.

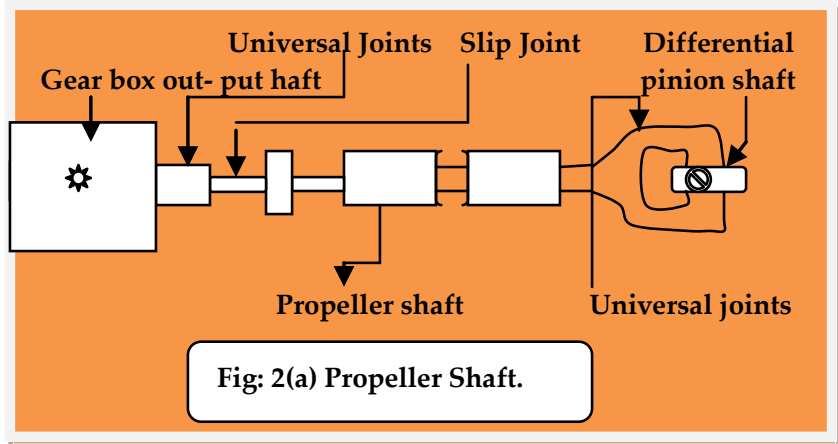

The propeller shaft may be hollow or solid as per design. In the case of cars and pick-up van , it is a single length and for the commercial heavy vehicles, it is in two length and single length shaft has two universal joints and a double length shaft has a third universal joint rear the center and the following, bearing cap mounting of propeller shaft. 
Dr Porag Kalita," Propeller Shaft in Automobile: Review the Allocation Procedure in Front Axle and springs", International Journal of Computer Engineering In Research Trends, Volume 3, Issue 9, September-2016, pp. 454-460

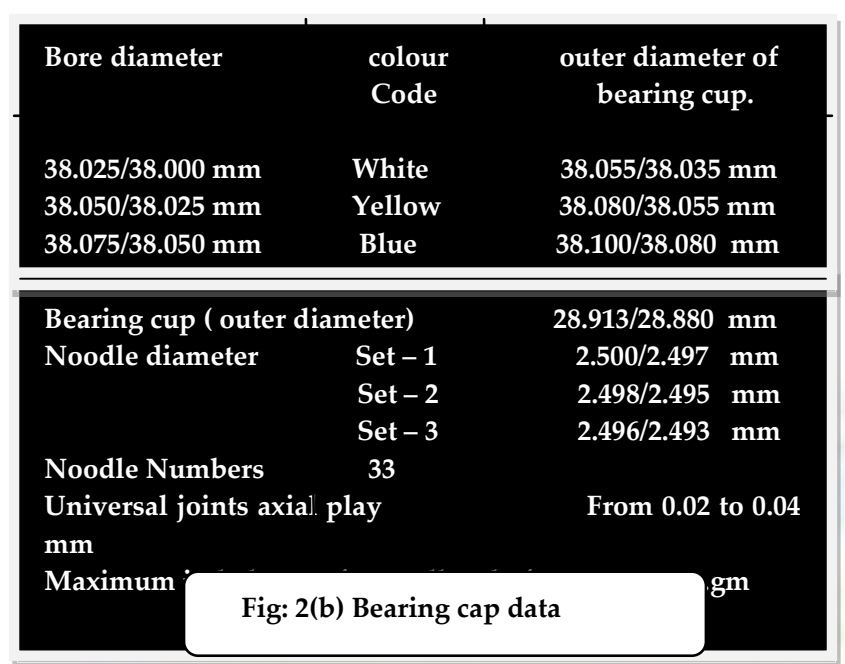

\section{LITERATURE REVIEW:}

The propeller shaft is designed for the given torque keeping in view the allowable stresses and discussed for the following.

$$
\frac{T}{I p}=\frac{f s}{y}
$$

Where $\mathrm{T}=$ the torque to be transmitted by the propeller shaft kg.cm.

$\mathrm{I}_{\mathrm{p}}=$ Polar moment of inertia of the section of shaft kg.cm ${ }^{4}$

$$
=\frac{\pi}{32}\left(\mathrm{~d}_{1}{ }^{4}-\mathrm{d}_{2}{ }^{4}\right) \mathrm{cm}^{4}
$$

$\mathrm{Y}=$ distance from the neutral axis to the outer most fiber of the shaft.

$=\frac{d 1}{2} \mathrm{~cm}$.

A factor of safety of 2 to 3 is also considered hence the torque should be multiple by factor of safety before calculating the dimension of propeller shaft.

For Example: Design a propeller for an automobile engine developing $40 \mathrm{hp}$ at 1500 rpm. The bottom gear ratio being 3.2 and the ratio of external dia of the propeller shaft and its internal dia is 1.8. Assumes a safe shear stress of $560 \mathrm{~kg} / \mathrm{cm}^{2}$ for the material of shaft.

Solution:

$$
\text { H. P. }=\frac{2 \pi N T e}{4500},
$$

Where, $\mathrm{T}_{\mathrm{e}}=$ Engine torque,

$$
\begin{aligned}
& \mathrm{N}=\text { Engine rpm, } \\
& 40=\frac{2 \pi \times 1500 \times T e}{4500} \text {, } \\
& \text { Or, } \mathrm{T}_{\mathrm{e}}=\frac{40 \times 4500}{2 \pi \times 1500} \\
& =19.1 \mathrm{~kg} / \mathrm{cm} \\
& =1.910 \mathrm{kgf} . \mathrm{cm}
\end{aligned}
$$

Torque to be transmitted by the propeller shaft: $=1.910 \times 3.2$

$$
=6100.00 \mathrm{~kg} \cdot \mathrm{cm}
$$

Now using the relation:

$$
\begin{aligned}
& \frac{T}{I p}=\frac{f s}{y} \\
& \frac{6100}{\frac{\pi}{\pi}((d 1 \mid 4)-(d 2 \mid 4)}=\frac{560}{(d 1 \mid 2)} \\
& \frac{6.100 \times 16}{\pi \times 560}=\frac{(d 1 \mid 4)-(d 2 \mid 4)}{d 1}=\frac{(1.8) 4(d 2 \mid 4)-(d 2 \mid 4)}{1.8 d 2}
\end{aligned}
$$

Or, $\quad 55.5=\mathrm{d}_{2} 2^{(5.15)}$

$\therefore \mathrm{sd}_{2}{ }^{3}=\frac{55.5}{5.15}=10.8$

$\therefore \quad \mathrm{d}_{2}=2.21 \mathrm{~cm}$

$$
\mathrm{d}_{1}=1.8 \times 2.21=3.98 \mathrm{~cm}
$$

External dia $=3.98 \mathrm{~cm}$

Internal dia $=2.21 \mathrm{~cm}$.

\section{METHODOLOGY:}

To every torque, there is an equal and opposite reaction. While the vehicle going to moving, the propeller shaft is moving clockwise direction and rotates along with drive pinion of the differential attached to it and the drive pinion pressed the crown wheel downwards direction. Hence, there is an opposite reaction against the differential housing tending it to turn in a directive opposite to that of the driving wheels and normally, it is known as rear and torque and which has to be prevented and therefore, front axle play important rules. 
Dr Porag Kalita," Propeller Shaft in Automobile: Review the Allocation Procedure in Front Axle and springs", International Journal of Computer Engineering In Research Trends, Volume 3, Issue 9, September-2016, pp. 454-460

\begin{tabular}{|c|c|c|c|c|c|c|}
\hline Make & Type of & & Gear I & Ratio & & \\
\hline \multirow[b]{2}{*}{$\begin{array}{l}\text { Telco } \\
\text { Truck }\end{array}$} & \multirow[b]{2}{*}{$\begin{array}{l}\text { five speed and } \\
\text { reverse, synchro- } \\
\text { mesh device } \\
\text { With } 2^{\text {nd }}, 3^{\text {rd }}, 4^{\text {th }} \\
\text { And top }\end{array}$} & $1^{\text {st }} \quad 2^{\text {nd }}$ & $3^{\text {rd }}$ & $4^{\text {th }}$ & top & rev \\
\hline & & $8.02: 1 \quad 4.785: 1$ & 2.736:1 & 1.663:1 & $1: 1$ & $8.29: 1$ \\
\hline
\end{tabular}

The arrangement of rear and torque driving forces is consist by Hotchkiss drive and Torque tube drive. The Hotchkiss drive is most commonly used in automobiles.

Front axles have to resist, bending and shear stresses due to load supported by them and tensional stresses due to braking torque and completed the following observation:

\begin{tabular}{|c|c|c|}
\hline $\begin{array}{l}\text { Diameter } \\
\text { King pins } \\
(\mathrm{mm})\end{array}$ & $\begin{array}{l}\text { I-Beam } \\
\text { King pins } \\
\text { diameter } \\
(\mathrm{mm})\end{array}$ & $\begin{array}{l}\text { Stub axle bushing } \\
\text { inside diameter } \\
\mathrm{mm}\end{array}$ \\
\hline $\begin{array}{l}\text { Standard } \\
\text { 34-991-34-980 } \\
\text { Standard - I } \\
35.291 \text { - 35.280 } \\
\text { (Repairing) }\end{array}$ & $\begin{array}{l}34.975-34.3950 \\
35.275-35.250\end{array}$ & $\begin{array}{l}35.025-35.064 \\
35.325-35.364\end{array}$ \\
\hline $\begin{array}{c}\text { Size - I } \\
\text { (Repairing) } \\
35.591-35.580\end{array}$ & $35.575-35.550$ & $35.625-35.064$ \\
\hline $\begin{array}{c}\text { Size - II } \\
35.891-35.880\end{array}$ & $35.875-35.850$ & $35.925-35.964$ \\
\hline
\end{tabular}

After rearming, I-Beam distance: $7 \mathrm{~mm}$ (minimum), Maximum run out from steering knuckle: $0.05 \mathrm{~mm}$. to wheel bearing.

Radial clearance in between of $\quad: 0.17-0.042 \mathrm{~mm}$ King pins and bush.

Stub axle I - Beam end play: $0.025-0.1000 \mathrm{~mm}$

Axial play of hub bearing: $0.01-0.100 \mathrm{~mm}$

Actual : $\quad 0.04-0.08 \mathrm{~mm}$

Toe -in $\quad: 1.3 \mathrm{~mm}$

Caster (positive) : $1^{\mathbb{E}} \pm 30^{\approx}$

King Pin inclination: $9^{=} \cdot 30^{\approx}$

Camber (positive): $1^{2}$

Wheel lock angle: $38^{\circ}\left(42^{\circ}\right.$ for $\left.L F O\right)$

Fig: 4(b) Front Axle Data
Front axle made by low carbon steel and therefore, bending and shear stresses easily. The axle supported by beam at the end and loaded vertically downwards at the center of spring pads. The maximum value of bending moment $\mathrm{W}$, is load on one wheel and 1 is the distance between the centers of wheel and the spring pads.

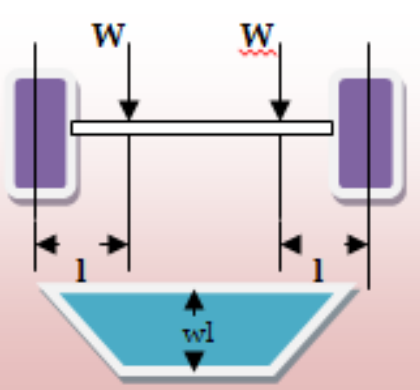

Fig: 4 (c) Bending moments

When the vehicle is running on the road, the value of bending moment has to increase by means of road roughness, for which a factor of safety must be accounted while designing it. Basically, the axle used is I section for the following formula:

$$
\frac{\mathrm{M}}{\mathrm{I}}=\frac{\mathrm{f}}{\mathrm{y}}
$$

Where,

$\mathrm{M}=$ Maximum bending moment $\mathrm{kg} . \mathrm{cm}$

$\mathrm{F}=$ allowable bending stress $\mathrm{kg} / \mathrm{cm}^{2}$

$\mathrm{I}=$ moment of inertia of the section of beam $\mathrm{cm}^{4}$

$y=$ Max Distance of the fiber from neutral axis.

A horizontal bending moment may be subjected upon the front axle due to resistance to motion. However, small magnitude its effect can be neglected. The resistance to motion also causes a torque in the case of drop forged axles. The magnitude of the torque $=\mathrm{R} \times \delta$

The shear stress on the axle is depending from and to braking torque whose magnitude = $\mu . W . r$.

Where, $r=$ the road wheel radius, 
Dr Porag Kalita," Propeller Shaft in Automobile: Review the Allocation Procedure in Front Axle and springs", International Journal of Computer Engineering In Research Trends, Volume 3, Issue 9, September-2016, pp. 454-460

$\mu=$ Coefficient of adhesion between road and tyre.The total amount of braking torque lying between the spring pads is less and formula is $\mu W(r-\delta)$. The front axle is made I-section between the lengths of spring pads because the length of spring pads because bending moment predominates in this portion and gradually changed to circular, oval or rectangular section at the steering because torsion predominates here and the following formula:

$$
\frac{T}{I}=\frac{f s}{y}
$$

For example: Design a suitable I-section for the front axle the following data:

Total weight of car $\quad=1400 \mathrm{~kg}$.

Load taken by front axle $=650 \mathrm{~kg}$.

Wheel track $=140 \mathrm{~cm}$

Working stress $=900 \mathrm{~kg} / \mathrm{cm}^{3}$

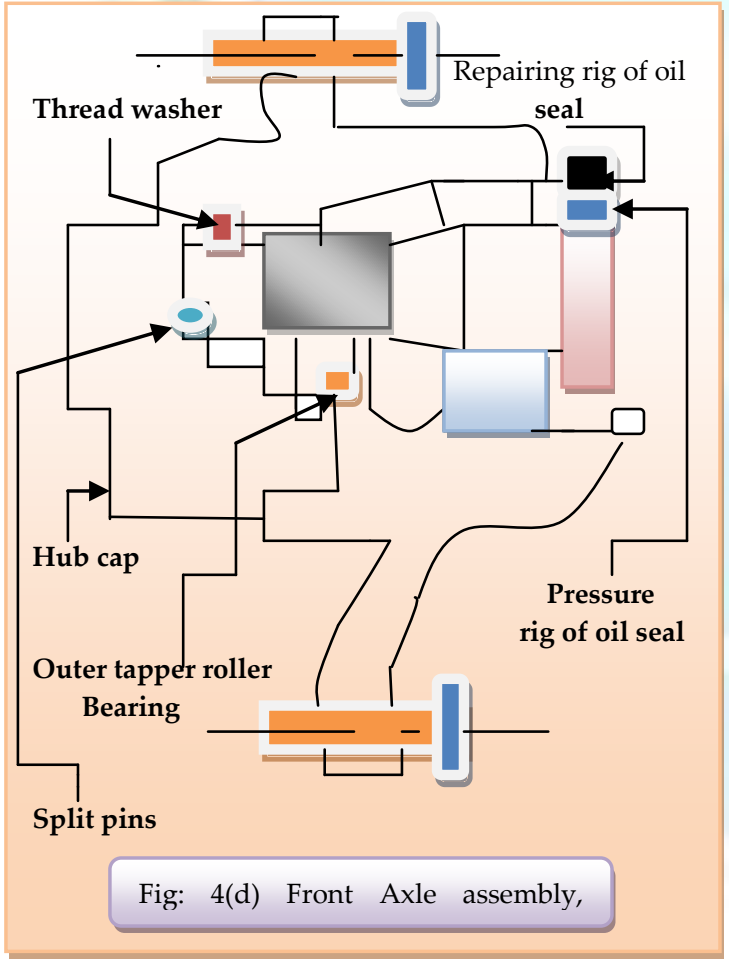

Distance between the centers of the spring

Pads $=70 \mathrm{~cm}$ width of flange and thickness are 0.6 and 0.2 of the overall depth of the section, Thickness of the web $=0.25$ of width of flanges.

Solution:

Maximum bending moment $=325 \times 35$

$$
=11.380 \mathrm{~kg} \text {. }
$$

Assuming overall depth of I-section $=\mathrm{d} \mathrm{cm}$,

Flange width $=0.6 \mathrm{~d}$

Flange thickness: $0.2 \mathrm{~d}$

Web thickness: $0.25 \times 0.6 \mathrm{~d}=0.15 \mathrm{~d} . \mathrm{cm}$.

$$
\begin{gathered}
\left.\mathrm{I}=\frac{1}{12} \times\left[0.6 \times \mathrm{d} \mathrm{x} \mathrm{d}^{3}-0.45 \mathrm{~d}(0.6 \mathrm{~d})^{3}\right)\right] \\
=\frac{1}{12}\left[0.6 \mathrm{~d}^{4}-0.45(0.6)^{3} \mathrm{~d}^{4}\right] \\
=\frac{0.6}{12} \mathrm{~d}^{4}[1-0.162] \\
=0.0419 \mathrm{~d}^{4} \mathrm{~cm}^{4}
\end{gathered}
$$
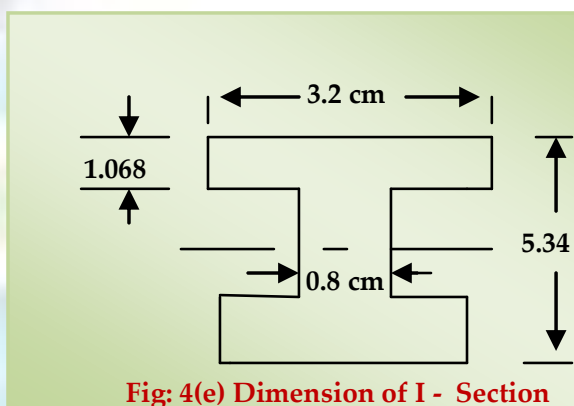

Fig: 4(e) Dimension of I - Section

$$
\begin{aligned}
& \frac{11.380}{0.0419 d 4}=\frac{900}{d / 2} \\
& \text { Or, } \mathrm{d}^{3}=\frac{11.389}{10.419 \times 2 \times 900}=151.0
\end{aligned}
$$

: $\mathrm{d}=5.34 \mathrm{~cm}$

The dimensions of I-Section are as follows:

Width of flange $=0.6 \times 5.34$

$$
=3.20 \mathrm{~cm}
$$

Thickness of flange $=0.2 \times 5.34$

$$
=1.068 \mathrm{~cm} \text {. }
$$

Web thickness: $0.15 \times 5.34$

$$
=0.8 \mathrm{~cm} \text {. }
$$

\section{RESULT \& DISCUSSION:}

The Hotchkiss drive is most commonly used in automobiles and comprises two longitudinal rear leaf springs and open type of propeller shaft. 
Dr Porag Kalita," Propeller Shaft in Automobile: Review the Allocation Procedure in Front Axle and springs", International Journal of Computer Engineering In Research Trends, Volume 3, Issue 9, September-2016, pp. 454-460

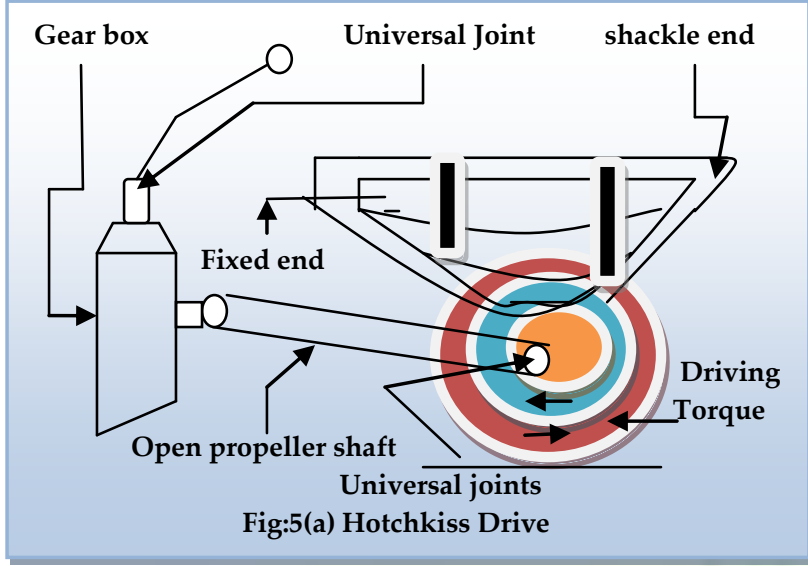

The spring leaf of the front side is connected with frame and rear side by shackled end. The open propeller shaft has provision to vary its length when the rear springs get deflected and has two joints and rear end torque is restricted by the springs and these get deflected while driving fast and vice-versa while braking. The bolt of the center has to tight enough along with springs. Thus both rear end torque and driving thrust are restricted by springs.

Springs support the chassis frame over which falls the weight of engine, power train, body, passengers etc. They damp the road shocks transmitted to the wheels as they over the road, thereby protecting the units supported directly By the frame. The Hotchkiss drive type of drive the springs have to bear driving thrust effects in addition to their springing action.

Leaf springs carriage springs are used in the vehicles to cushion the shocks impaired to the wheels by road obstacles. In case of breadth is kept constant and the depth is varied Instead of one solid block a leaf spring is built up of a number of overloading leaves, laminations or plates, each of same breadth $b$ and thickness or depth $\mathrm{d}$. The modulus section $\left(\mathrm{Z}=\frac{I}{y}\right.$ ) at any section of the spring of the spring is $n \frac{b d 2}{6}$, where $\mathrm{n}$ is the number of laminations at the section under consideration.
Springs are placed between the chassis frame and axles and it is consisting by Leaf springs, Coil Springs and Torsion Bars. Leaf springs are elliptical shape and for example, Semi Elliptic type of springs is forming the shape of half ellipse.

Helical springs, the function is that these springs is to absorb shocks e.g. springing vehicle, to return an element to its original position when it has been temporarily displaced and following quantities are involved in the study of these springs:

$\mathrm{R}=\frac{D}{2}=$ mean radious

$\mathrm{W}=$ applied load on the spring, (kg.)

$\mathrm{d}=$ diameter of wire, $(\mathrm{cm})$

$\delta=$ Deflection, $(\mathrm{cm})$,

$\mathrm{p}=$ pitch of the coils, $(\mathrm{cm})$

$\mathrm{n}=$ effective number of coils in the spring,

$1=$ working length of the spring, $(\mathrm{cm})$,

$$
=2 \pi R \times n
$$

$\mathrm{N}=$ modulus of rigidity, $\mathrm{kg} / \mathrm{cm}^{2}$

$\mathrm{J}=$ polar moment of inertia, $\frac{\pi}{\pi 2} \mathrm{~d}^{4} \mathrm{Cm}^{4}$

$\mathrm{C}=$ Spring index, $\frac{D}{\mathbb{Q}}$

Torsional moment: $\mathrm{T}=\frac{W D}{2}$

Shearing stress due to torque $\mathrm{T}$ is:

$$
\mathrm{f}_{\mathrm{s}}=\frac{T \cdot R}{J}=\frac{W \cdot D \times 16}{2 \times \pi d 3}=\frac{16 W R}{\pi d 3}
$$

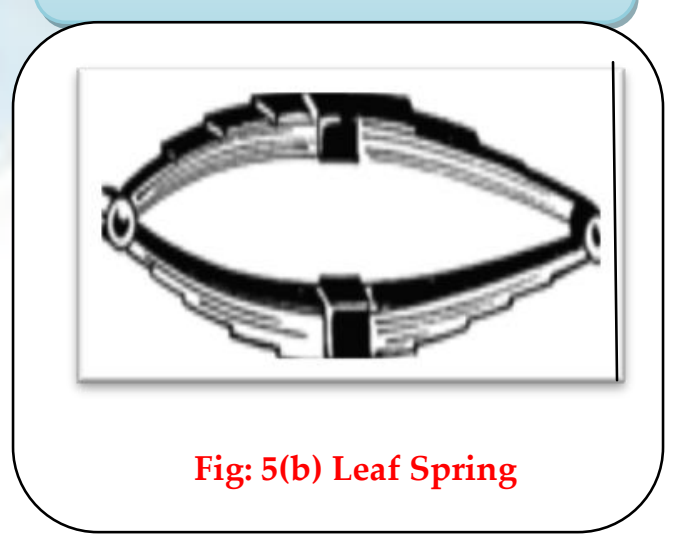


Dr Porag Kalita," Propeller Shaft in Automobile: Review the Allocation Procedure in Front Axle and springs", International Journal of Computer Engineering In Research Trends, Volume 3, Issue 9, September-2016, pp. 454-460

For example: Design a closed coil helical spring for the service load ranging from 230 to $270 \mathrm{~kg}$. The axial compression of spring for that range is $\mathrm{mm}$. Spring index $5 . \mathrm{f}_{\mathrm{s}}=4000 \mathrm{~kg} / \mathrm{cm}^{2}$ and $\mathrm{N}=8.3$ $x 10^{5} \mathrm{~kg} / \mathrm{cm}^{2}$.

Solution: The diameter of the spring wire is calculated from the stress equations keeping in view that the shear stress in spring should not increase beyond $4000 \mathrm{~kg} / \mathrm{cm}^{2}$ under the maximum load of $270 \mathrm{~kg}$.

Hence,

$$
\begin{array}{ll} 
& T=W \times R=\frac{\pi}{16} d^{3} f^{s} \\
\text { Or, } & 270 \times 2.5 d=\frac{\pi}{16} d^{3} \times 4000 \\
\therefore & d^{3}=0.86 \\
\therefore & d=0.926 \mathrm{~cm} \text { say } 1 \mathrm{~cm} .
\end{array}
$$

Hence mean diameter of coils is $=5 \times 1 \mathrm{~cm}$ outside and inside diameter of spring are $5+1=$ $6 \mathrm{~cm}$ and 5-1 $=4 \mathrm{~cm}$ respectively.

Effective number of coils is calculated from the deflection equation keeping in view that the compression of $7 \mathrm{~mm}$ is produced by the force $270-230=40 \mathrm{~kg}$.

$$
\begin{aligned}
& \text { i.e. } \delta=\frac{64 W R 3 \times n}{N \times d 4} \\
& 0.7=\frac{64 \times 40 \times(2.5) 3 \times n}{8.3 \times(10) 5 \times(1) 4} \\
& \mathrm{n}=14.8 \text { say } 15 \text { coil. }
\end{aligned}
$$

As the spring, is to rest on the supports, which takes about $1_{\mathrm{n}}^{\frac{1}{2}}$ turns.

Total number of turns $=15+1.5=16.5$ say 16 , Maximum compression produced under the maximum load is: $0.7=\frac{270}{270-230}=4.7 \mathrm{~cm}$,

Here, $\delta$ is proportional to $\mathrm{W}$,( other constant),

$\therefore \quad$ free length $=15 \times 0.1+16 \times 1+4.7$

$$
=21.5 \mathrm{~cm} \text {. }
$$

\section{TYPE OF DATA:}

Gear ratio means, the ratio of the input revolution to output revolutions of a gear system and it is an important factors for propeller shaft, because the distance between gear box and differential changes when the vehicle encounters an uneven surface. This change varies the effective length of the propeller shaft and the following data for gear ratio in sliding mesh gear box.

Gear Ratio $=\frac{\text { No of teeth of the driven gear }}{\text { No of teeth of the driving gear }}$

\subsection{Ist gear:}

$$
\frac{\text { No of teeth on main shaft Ist gear }}{\text { No of teethonlay shaftIst gear }}=\frac{49}{17}
$$

Gear ratio: $\frac{4 a}{17} \times \frac{4 a}{17}=6.39$

Ist gear ratio: 6.39

6.2. $2^{\text {nd }}$ Gear:

$$
\begin{array}{r}
2^{\text {nd }} \text { gear }=\frac{\text { No of teeth of main shaft } 2 \text { nd gear }}{\text { No of teeth of lay shaft } 2 \text { nd gear }}=\frac{33}{27} \\
2^{\text {nd }} \text { gear ratio }=\frac{4 \mathrm{II}}{17} \times \frac{\mathrm{an}}{27}=3.09 \\
2^{\text {nd }} \text { gear ratio }=3.09
\end{array}
$$

\section{3. $3^{\text {rd }}$ Gear :}

$$
\begin{array}{r}
3^{\text {rd }} \text { gear: } \frac{\text { No of teeth of main shaft } 3 \text { rd gear }}{\text { No of teeth of lay shaft } 3 \text { rd gear }}=\frac{24}{36} \\
3^{\text {rd }} \text { gear ratio: } \frac{4 \pi}{17} \times \frac{24}{a 6}=1.68 \\
3^{\text {rd }} \text { gear ratio }=1.68
\end{array}
$$

6.4. Top Gear :

$$
\text { Top gear : 1:1 }
$$

\subsection{Reverse Gear :}

Reverse gear $=\frac{\text { No of teeth on layshaft gear }}{\text { No of teetrhon ideling gear }} \times$

No of teeth on main shaft lst gear

No of teeth of main shaft

Reverse gear: $\frac{41}{17} \times \frac{22}{17} \times \frac{43}{18}=7.819$

The reverse gear ratio: 7.819 
Dr Porag Kalita," Propeller Shaft in Automobile: Review the Allocation Procedure in Front Axle and springs", International Journal of Computer Engineering In Research Trends, Volume 3, Issue 9, September-2016, pp. 454-460

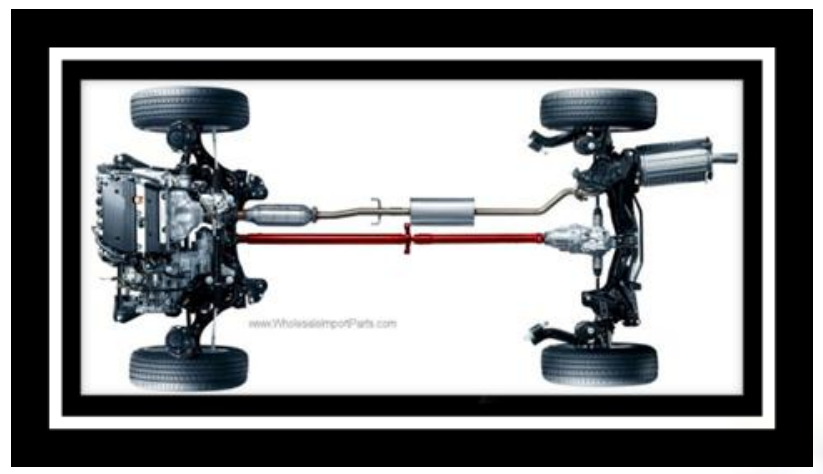

Fig: 6(a) view of Chassis with propeller shaft.

\section{CONCLUSION:}

Drive shaft means which drive is given to the driving axle. Drive shaft known as propeller shaft by means of which power from transmission is transmitted to the driving axle at varied lengths and varied angles. Drive axle which drive goes to the wheels and it is known as live axle since power flows through it and the following purpose, i.e. it acts as a beam to support the weight of the body; it acts as an axis for the wheels; it transmit power to the wheels, etc. The connection of stub axle with the axle beam or steering knuckle support is through a yoke and kingpin. Yoke for hanging stub axle with the axle beam at the end of axle beam, known as Elliot type arrangements or front axle. From the above discussion, Factors affecting steering in an automobile is directly or indirectly is depending:

[7.1] Steering gear ratio and back lash.

[7.2] Tyre pressure

[7.3] condition of king pins and bushing, etc.

\section{REFERENCES:}

[1] Book on Automobile Design problem, by Mr. Agrawal, India.

[2] Book ISBN No. 8121902142 , by H.B. Singh Reyat, Punjab.

[3] Course Material, Workshop Manager Training programme, Telco, Jamshedpur, 1993.

[4] www.alibaha.com

[5]Service Manual, Maruti Udyog Ltd, N. Delhi.
[6] Training Programme in Telco, M/S Gargo Motors, Assam, 1993.

\section{ACKNOWLEDGEMENT:}

I would like to thanks my son Mr Alakesh Kalita, Student of B. Tech in Engineering Physics ( $1^{\text {st }}$ Semester- Dual) in Indian Institute of Space Science \& Technology, Government of Space, Kerala for the valuable cooperation .

\section{ABERRATIONS / ACRONYMS:}

Flange: Provided with a projecting flat rim, collar or rib.

Flange Coupling: A shaft coupling consisting of two accurately faced flanges which are keyed to their respective shafts and bolted together.

King Pins: Large bolts specially designed which are used to attach the stub axle to the main shaft or steering assembly.

Stub axle: A short axle attached to the main axle or to the steering assembly upon which the front wheels revolve. The stub axle pivots around the king pins. 